\title{
On the Viability of Vocabulary Learning Enhancement through the Implementation of MALL: The Case of Iranian EFL Learners
}

\author{
Parviz Alavinia \\ Urmia University, Iran \\ Kamel Qoitassi \\ Urmia Islamic Azad University (Science and Research Branch), Iran
}

\begin{abstract}
The augmented interest, at the wake of the new millennium, apropos different modes of computer assisted instruction gave rise to the naissance of a new generation of CALL-based research known as MALL. As research over MALL might be said to still be in its infancy, a multitude of untouched areas remain to be dealt with, among which mention can be made of the way mobile assisted programs can bring about a better implementation of vocabulary instruction. Hence, in the current study, the viable effect of using MALLoperated vocabulary instruction technique on the process of vocabulary acquisition has been scrutinized. To this aim, forty elementary learners (all females) studying at the Iran Language Institute (Mohabad branch, Iran) were selected. To tap the data, the researchers utilized a variety of instruments including questionnaire, interviews, and a multiple-choice vocabulary test. The statistical analysis was mainly carried out through the use of ANCOVA. In tandem with the gained upshots, it was revealed that treatment through the application of mobile assisted vocabulary learning had been quite effective in improving learners' vocabulary acquisition. The results also indicated that the use of this technique had been effective in changing the learners' attitudes towards the proper use of mobile phones for pedagogical purposes.
\end{abstract}

Index Terms-MALL, SMS (Short Message Service), text messaging, MALL-operated vocabulary instruction

\section{FOREWORD}

Once-queer terms and notions like connectivity, computer and mobile-assisted language learning, synchronous learning as well as computer and mobile-mediated communication have now turned to commonplace verities in today's technologized world. As Benson and Chik (2010), among other, hold "emerging globalized online spaces provide new opportunities for language learning to occur autonomously as part of learners' everyday literacy practices" (cited in Hafner \& Miller, 2011, p. 70).

In the fast moving world of educational technology, innovative but unusual ways of meeting the ever-changing learning needs of people are proposed. In this world, where individualization is the catchphrase (Chaudron, 2000; Horwitz, 2000; McGinley, 2006; Yu, 2007), institutions hinge mainly on e-learning capacities for coordination of their various activities, for example, simultaneously working on a project physically scattered. Today, every big or small institution wants to incorporate e-learning in their system. This has resulted in a wide array of tools in the market for elearning programs where every kind of help is easily available in this regard. What is happening to the society and social networks by the ever-progressive movement of technology is aptly put by Peters (2007),

Technological advancements that allow fast communications and information processing are supporting new social patterns. As a result, communities are no longer only based on geographical proximity, and new 'tribes' (Rheingold, 2002) are developing and disbanding according to interest, work patterns, and opportunity. (p. 1)

Mobile learning (m-learning) is a field which combines mobile computing and e-learning. But does m-learning play an essential role like what the Web did? It is not clear as of yet, but we must attempt to find an answer to the question, by trying to imagine how mobile devices can improve e-learning or hinge it. With the inevitable integration of mobile technology into our lives, we can claim that it has already become a familiar part of the everyday lives of the majority of teachers and learners in Iran. But not surprisingly, its use as an educational tool has not been very apparent compared to its non-educational uses. Mobile phone as a learning tool can be one of the manifold innovative and exciting ways of grappling with learners' needs.

A quotable, challenging statement indicating the necessity of integrating m-learning with pedagogical attempts would be that of Akenaga (2005), who remarks that "today's students are more technology savvy than the university staff and officials, and they expect their needs to be met anywhere, anytime and with any device" (p. 12). In the current study the researchers strive to look into the effectiveness of one of the uses of mobile phones as educational tools to be utilized both by Iranian EFL learners to improve and support their learning, and by their teachers to enhance and enrich their 
teaching. Of the many possible educational uses of mobile phones, the researchers focus on the students' use of text messages made available for them. Finally, they probe into the learners' attitudes toward this MALL application.

Perhaps it can be claimed that mobile-assisted language learning, as Godwin-Jones (2011, p. 2) states, "is in itself not new, but new devices with enhanced capabilities have dramatically increased the interest level, including among language educators." Nonetheless, literature on the value of MALL is drastically meager and, as of yet, in the Iranian context only few scholars have attempted to carry out in-depth probes into varied aspects of its usefulness. In an attempt to fill this gap in the literature, the researchers aimed to analyze Iranian EFL learners' attitudes toward the effectiveness of MALL through the use of text messages, whereby they tried to show some of the workable ways of implementing and integrating mobile phones in(to) the teaching-learning process. Thus, in an attempt to come up with satisfactory expositions for the study postulations, the following research questions were formulated:

1. Does the use of MALL and particularly mobile-based text messages have any effect on Iranian EFL learners' vocabulary enhancement?

2. What are the Iranian EFL learners' attitudes toward MALL?

2a. In what ways, if any, do Iranian EFL learners perceive MALL use in their learning activities?

2b. How do they view the effect of mobile-based text messages on their vocabulary acquisition?

2c. How do their beliefs affect their context and patterns of use of the technology?

2d. What are the factors, if any, Iranian EFL learners perceive to be impeding MALL practice?

2e. What are their suggestions on actions to be taken to make MALL practice more effective?

\section{Language Learning and Technology}

To adopt Hafner and Miller's (2011, p. 70) words, "in order to develop an approach to technology capable of fostering learner autonomy we must recognize that pedagogy and technology are inter-related." Indeed, two of the principal souvenirs of technology for human beings in the recent decades have been PCs/laptops and cell phones, which have now made their way to and through the pedagogical arenas in most schools, institutes, and colleges throughout the globe. In the section that follows, a brief account is provided of the two resultant trends of this prevalent technological growth, referred to as CALL (Computer Assisted Language Learning) and MALL (Mobile Assisted Language Learning).

\section{Recent Empirical Research on CALL \& MALL}

As Tanner and Landon (2009, p. 51) point out "Computer-Assisted Language Learning (CALL) is of interest to language teachers and learners because it can provide individualized instruction and immediate feedback on the correctness of a learner's response to computerized tasks." Though research on CALL has taken different orientations in the recent years, two dominant perspectives CALL-oriented probes seem to have targeted are attitudes toward the implementation of CALL and different skill-related gains resulting from the utilization of CALL programs.

Amongst the vast body of research on different educational stakeholders' attitudes toward the use of technology in education reference can be made to Eswaran's (2008) work, where the researcher was interested in probing both learners and teachers' attitudes toward the exploitation of computers as tools facilitating teaching/learning processes. In this small-scale study, the researcher tapped six English teachers and thirty two students' views regarding the classroom use of CALL through the administration of two sets of questionnaires, and found that the majority of participants were avid concerning the application of computers as beneficial language learning aids and thought its use can act as a potential motivator for furthering learning.

In like manner, Bordbar (2010) sought to pinpoint the main incentives underlying the instructors' use of computers for language teaching. Benefiting from the participation of 83 high school EFL teachers, the researcher ran a survey on teachers' perspectives regarding the use of CALL in learning environments, and concluded that prior experience with the application of CALL can function as a determining factor in fostering its later use, whereas some impediments such as inadequacy of time and resources are liable to bring about a demise in classroom use of CALL. Overall, the findings of Bordbar's research were indicative of teachers' highly positive outlook toward the implementation of computers as an influential means for language learning.

Within the recent literature on the use of CALL for the enhancement of diverse aspects of learning, one comes across several instances reporting the efficacy of CALL programs for various learning outcomes. As a case in point, Sauro (2009) was interested in gauging the potential impact of computer-mediated corrective feedback on the enrichment of learners' grammar knowledge. Through the utilization of two types of computer-mediated corrective feedback (by providing feedback in the form of recasts or metalinguistic information) with some 23 English learners, then, the researcher concluded that there was "no significant advantage for either feedback type on immediate or sustained gains in target form knowledge, although the metalinguistic group showed significant immediate gains relative to the control condition." (p. 96).

In a similar vein, Vinagre and Muñoz (2011) investigated the possible effect of peer computer-mediated corrective feedback on the augmentation of learners' accuracy. To perform the study, 17 Spanish and German learners were asked to get involved with the task of e-mail exchange for a period of three months. At the culmination of the study, they found that "despite frequent use of error correction, the use of remediation led to a higher percentage of errors recycled and was more conducive to error recycling in later language production" (p. 72). 
Tanner and Landon (2009), on the other hand, embarked on an exploration dealing with the role of computers in bringing about more intelligible pronunciation production by learners, particularly with regard to suprasegmentals. A total of 75 ESL students were used as the participants of this study, and in order to apply the desired treatment, use was made of 'Cued Pronunciation Readings' with the aim of fostering self-directed pronunciation practice in learners. The findings of these researchers' study were indicative of significant gains among the experimental group participants in terms of production and perception of suprasegmental features especially as it regards pausing and word stress.

Subsequent to the succinct account provided concerning recent CALL-oriented research, the researchers are now going to turn to a brief review of some of the recent probes in the realm of mobile assisted language learning. Mlearning research which was once plagued with myriad "limitations inherent in the devices, in particular small, lowresolution screens (problematic for image/video display or even good text reading), poor audio quality (both in phoning and audio playback), awkward text entry, limited storage/memory and slow Internet connectivity" (Godwin-Jones, 2011, p. 2), has now entered a revolutionary stage in the recent years with the advent of novel systems and technologies. As Stockwell (2010) maintains, "mobile technologies have started to make their presence felt in the field of education, as can be seen by the increasing number of publications that have appeared in recent years" (p. 95).

According to Kukulska-Hulme and Shield (2008) "MALL differs from computer-assisted language learning in its use of personal, portable devices that enable new ways of learning, emphasizing continuity or spontaneity of access and interaction across different contexts of use." Generally speaking, the use of mobile phones, MP3/MP4 players, PDAs and palmtop computers is expected to be part of MALL. Since MALL is in its embryonic stage, the studies are sketched based on different criteria by different people, for example one can categorize them as those done to find a theoretical justification for m-learning versus those aimed at implementing some of the practices already followed in computerassisted language learning and other forms of learning-enhancing technologies like CD-ROMs, MP3/MP4 players, television, radio and the like. Another categorization might be that employed by Kukulska-Hulme and Shield (2008) who classified the literature on MALL as those studies which approach MALL placing the locus of focus on the content to be delivered versus those emphasizing the design-related issues.

Though studies on mobile-assisted language learning have taken diverse directions in the recent years, due to the researchers' concern with vocabulary learning in the light of MALL in the current study, an attempt is made hereby to go over some recent relevant work that address the use of cell phones for furthering learners' vocabulary repertoire. Stockwell (2010), for instance, launched an M-learning research project with 175 pre-intermediate English learners, in a stab aimed at exploring the effectiveness of utilizing cell phones for getting engaged with the vocabulary activities. Indeed, the use of mobile phones as vocabulary learning aids was investigated in this study and its upsides were discussed in comparison to the use of computers.

Other instances of recent probes regarding the use of mobiles for assisting vocabulary learning include Thornton and Houser's (2005) work which discusses the utilities of using mobiles for both learning and evaluating the knowledge of English idioms, Browne and Culligan's (2008) study, which reports on the practicality of using vocabulary learning flash cards on the cell phones, Chen, Hsieh, and Kinshuk's (2008) probe which addresses the use of varied mobileassisted vocabulary learning strategies for learners with different learning preferences, and Kennedy and Levy's (2008) research which touches the positive effects of vocabulary reinforcement through contextualized mobile-assisted practice outside the classroom via sending short messages (cited in Stockwell, 2010)

\section{METHOD}

To meet the objectives of the present study, a mixed method research strategy was adopted and to perform the study, ILI (Iran Language Institute), Mohabad branch, was chosen as the major venue. The methodology of research included using a questionnaire, ILI classroom vocabulary test, as well as semi-structured interviews with Elementary learners. Fieldwork was carried out for data collection from June 2011 till September 2011. Twenty out of the total population of forty students were selected at random, and were interviewed about their professional development and different aspects of using SMS on their cell phones. Interviews were recorded and conducted in Mohabad. All research participants gave their verbal consent to the recording of their interviews, as well as having them used for research purposes.

\section{Participants}

The participants of the study were a group of female students studying at Mohabad ILI (Iran Language institute), Iran. They were studying English Elementary course for two sessions a week at the ILI, with each session lasting for one hour and forty five minutes. The total number of participants amounted to 40 .

\section{Instrumentation}

To gather data the researchers made use of a questionnaire, interviews, and a multiple-choice vocabulary test, a brief explanation of which is provided in the ensuing section.

\section{MALL Questionnaire}

When the researchers finished writing up the first draft of the MALL questionnaire, to go about the validation process following Alderson and Banerjee (2001, as cited in Milanovic, 2007), they gave a copy to seven ELT experts to review, have comments and write their expectations of what a MALL questionnaire should contain. Heeding their comments, the researchers made some modifications to the original version. 
The questionnaire, which was administered on the first and last days of the course, gathered general information on experimental group participants' use of and attitudes toward mobile phone in general and MALL-related applications/facilities in particular, that is, their attitudes toward the use of SMS. The questionnaire also investigated the amount of MALL training and experience, and degree of skillfulness in MALL utilization as perceived by the participants. It finally contained items on personal specifications of each participant, such as their gender, number of years spent studying English, etc.

Based on the statistical analysis, as well as feedback by student respondents and teachers with regard to the readability of items, the refined version of SMS questionnaire consisting of nine items, was piloted prior to the main study $(\mathrm{N}=20)$. Although the Cronbach's Alpha (CA) values of 8 questions were identified marginal $(0.73,0.83$ and 0.71$)$ and 3 questions were inadequate $(0.66,0.62$ and 0.61$)$, the overall internal reliability was measured at 0.87 . In addition, deleting any of the questionnaire items did not increase the reliability of SMS. This indicated that all the items contributed to the reliability of SMS questionnaire. It can thus be claimed that the items in SMS questionnaire have high internal consistency and none of them should be dropped from the overall measure of students' attitude toward SMS application.

\section{Semi-Structured Interviews}

Consisting of nine questions each related to one or more of the items on the MALL questionnaire, the interviews were constructed to triangulate the information gathered through the MALL questionnaire. Taking 15 minutes each, the interviews were conducted after the preliminary analysis of data collected through the MALL questionnaire. While carrying out the interviews, which were written on some papers and audio-taped so that they could be attached and analyzed later on in the data analysis phase of the study, the researchers spent about two or three minutes on each question. The same procedure was followed after the second administration of the questionnaire toward the end of the course.

\section{Vocabulary Test}

Searching the vocabulary section of many samples of the ILI examination questions available on the market and sampling the items to be covered in the course, the researchers managed to adapt a vocabulary test, containing 60 items, which was found to have a reliability index of .83, using the split-half method.

\section{Design of the Study}

Since investigating ideas and attitudes most often involves a qualitative type of study whereas analyzing the effectiveness of the experimentation demands a quantitative one (Cohen, Manion and Morrison, 2007, pp. 96-97), the researchers employed a mixed design for the study. For the qualitative part of the study, a questionnaire was developed based on the researchers' experience on and intuition about what might be of relevance to the application of MALL in the Iranian context. As a questionnaire alone is not enough to tap the participants' attitudes, after the administration of the questionnaire those participants who were at the extreme end of the cline, as far as their agreement/disagreement with MALL is concerned, were interviewed to make sure that their views are appropriately reflected in the study. For the second section of the study a pretest-posttest control group design was employed. The pretest was administered on the second session of the course, and at the end of the term the same test was re-administered to both groups as the posttest. With the help of SPSS version 19, running an ANCOVA test and independent samples T-test, the researchers compared the gained scores of the two groups on pre-test and post-test on the vocabulary exam to pinpoint the possible significant difference between their levels of accomplishment.

\section{Data Collection Procedure}

As for the first research question, which followed a quasi-experimental design, the learners were pretested on the vocabulary test adapted and validated by the researchers. Then, the participants who were already randomly assigned into two groups were presented with the course content for 18 consecutive sessions of one hour and forty five minutes each. At the end of the term period, both groups were given the same test to see how much they had achieved compared to one another.

Thus, subsequent to administration of the study questionnaire and running the interview with the learners in the experimental group, participants in both groups were given the multiple-choice test of vocabulary, which was adapted by the researchers from ILI collection of tests. To observe the ethicality concerns, at the outset of the study, all the participants were asked for their consent to take part in the study.

Successive to the administration of pretest, in the sessions that followed, the learners in the experimental group started to be sent message files containing some of the vocabulary items relevant to their course, whereas the control group learners didn't receive any treatment through vocabulary test messaging and continued their regular course of study with the ILI coursebooks.

The experimental group participants were also allowed to consult their mobile dictionaries to look up and resolve their problems or disambiguate any points of equivocalness. The researchers needed to help the learners with how to use the resources available to them. It is also worth mentioning that the ILI textbooks, on which the current work was based, are a multi-skill eclectic series mainly centering around grammar, and hence a considerable amount of time in both groups was allotted to the explication of grammatical points.

At the end of the term, the very 9-item questionnaire was given to the experimental group learners to see how much their attitudes had changed and how helpful they found MALL to be. After coding the data gathered through the 
questionnaire, analyzing the interview for content schemes and doing the numerical calculations, the data collected from the two administrations were visually represented and compared to show the degree and direction of change of attitudes (if any).

\section{Data Analysis}

The first part of the study, being guided by the first research question, dealt with the effects on Iranian EFL learners' vocabulary acquisition of their use of Text Messages. To be able to pinpoint the possible gains within the experimental group, ANCOVA and independent samples T-test were run, the reason behind using the former being the prior administration of questionnaire and interview to the experimental group participants. The second part, being guided by the second overarching research question, concerned the Iranian EFL learners' attitudes toward the effectiveness of the implementation of cell phones as now-ubiquitous technological tools. To that end, a questionnaire and follow-up interviews were employed. The correspondence of the items of the questionnaire and interview themes constituted the basis of answering the second general research question.

\section{RESUlts}

\section{Quantitative finding}

In keeping with the manner in which the research questions of the study were organized, the researchers would rather first deal with the primary hypothesis of the research which was after finding the effect of SMS-operated vocabulary treatment on the enhancement of vocabulary learning. In this experimental and quantitative phase of the study, the data were analyzed using two alternative statistical procedures (ANCOVA as well as independent samples t-test) to ensure the verity and reliability of the gained results. Indeed, the reason behind running ANCOVA for the initial postulation of the study was to control for the viable effect of the prior questionnaire and interview sessions on the performance of experimental group. Table 1 through 4 below illustrate the statistical data gained through running ANCOVA, and Figure 1 shows the scatter of Levene's Test of Equality of Error Variances.

TABLE 1

TESTS OF BETWEEN-SUBJECTS EFFECT DEPENDENT VARIABLE: POST

\begin{tabular}{|l|l|l|l|l|l|l|}
\hline & $\begin{array}{l}\text { Type III Sum } \\
\text { of Squares }\end{array}$ & df & Mean Square & F & Sig. & $\begin{array}{l}\text { Partial Eta } \\
\text { Squared }\end{array}$ \\
\hline Cource & $769.692^{\mathrm{a}}$ & 3 & 256.564 & 300.545 & .000 & .962 \\
Intercept Model & 127.655 & 1 & 127.655 & 149.538 & .000 & .806 \\
group & 70.997 & 1 & 70.997 & 83.167 & .000 & .698 \\
pre & 45.881 & 1 & 45.881 & 53.746 & .000 & .599 \\
group * pre & 13.439 & 1 & 13.439 & 15.742 & .249 & .304 \\
Error & 30.732 & 36 & .854 & & & \\
Total & 9480.813 & 40 & 39 & & & \\
Corrected Total & 800.423 & a. R Squared = .962 (Adjusted R Squared = .958) & \\
\hline
\end{tabular}

LEVENE'S TEST OF EQUALITY OF ERROR VARIANCES ${ }^{\mathrm{a}}$

\begin{tabular}{|l|l|l|l|}
\hline \multicolumn{4}{|c|}{ DEPENDENT VARIABLE: POST } \\
\hline 3.940 & 1 & df1 2 & Sig. \\
\hline
\end{tabular}

TABLE 3

TESTS OF BETWEEN-SUBJECTS EFFECT

DEPENDENT VARIABLE: POST

\begin{tabular}{|l|l|l|l|l|l|l|}
\hline & $\begin{array}{l}\text { Type III Sum of } \\
\text { Squares }\end{array}$ & $d f$ & Mean Square & F & Sig. & $\begin{array}{l}\text { Partial Eta } \\
\text { Squared }\end{array}$ \\
\hline Corrected Model & $756.253^{a}$ & 2 & 378.126 & 316.743 & 000 & 945 \\
Intercept & 136.190 & 1 & 136.190 & 114.081 & 000 & 755 \\
pre & 40.114 & 1 & 40.114 & 33.602 & .000 & 476 \\
group & 604.834 & 1 & 604.834 & 506.648 & 000 & 932 \\
Error & 44.170 & 37 & 1.194 & & & \\
Total & 9480.813 & 40 & & & & \\
Corrected Total & 800.423 & 39 & & & & \\
\hline
\end{tabular}

a. R Squared $=.945$ (Adjusted R Squared $=.942$ )

TABLE 4

GROUP STATISTICS

\begin{tabular}{|l|l|l|l|l|}
\hline \multirow{2}{*}{ group } & \multirow{3}{*}{\begin{tabular}{l} 
Mean \\
\cline { 4 - 5 }
\end{tabular}} & Std. Error & Lower Bound & Upper Bound \\
\hline Exper. & $18.846^{\mathrm{a}}$ & .212 & 18.416 & 19.275 \\
Control & $10.893^{\mathrm{a}}$ & .213 & 10.461 & 11.325 \\
\hline
\end{tabular}




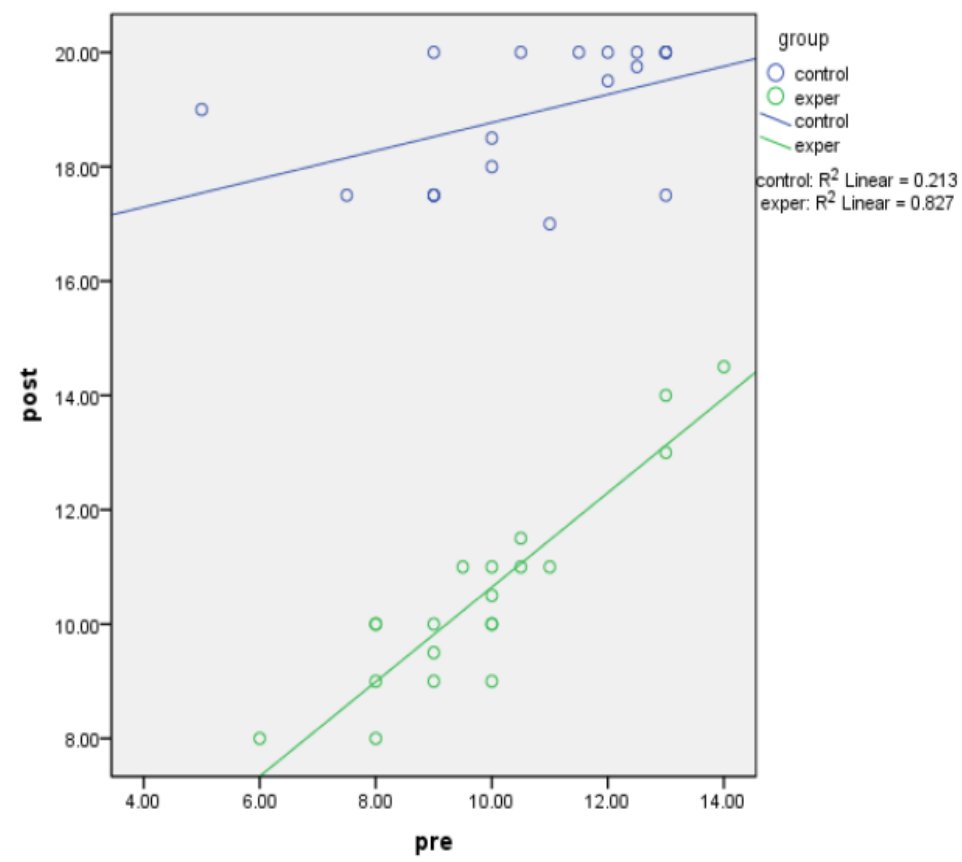

Figure 1 Scatter of 10 Levene's Test of Equality of Error Variances

Comparing the scores obtained on pretest and posttest, a significant difference was witnessed between the test takers $(p=.000)$ in two groups, and since the average of scores of experimental group participants (18.84), in which they were treated through the application of SMS for improving vocabulary, was found to be higher than the one for control group (10.89), it was concluded that the research hypothesis concerning the effect of SMS application on Learning Vocabulary was to be confirmed. As stated earlier, an alternative method of data analysis used in the current study with regard to the first research question was independent samples t-test, the findings of which are illustrated in Tables 5 and 6 below.

TABLE 5

GROUP STATISTICS

\begin{tabular}{|ll|l|l|l|l|}
\hline \multicolumn{2}{|c|}{ group } & N & Mean & Std. Deviation & Std. Error Mean \\
\hline \multirow{2}{*}{ score } & experimental & 20 & 8.6000 & 1.63514 & .36563 \\
& control & 20 & .7500 & .91047 & .20359 \\
\hline
\end{tabular}

TABLE 6

INDEPENDENT SAMPLES T-TEST

\begin{tabular}{|l|l|l|l|}
\hline \multirow{2}{*}{ score } & \multicolumn{2}{|l|}{} & \\
\cline { 2 - 4 } & $\mathrm{t}$ & $\mathrm{df}$ & Sig. (2-tailed) \\
\hline
\end{tabular}

Considering the level of significance reported in the above table $(0.000)$, once more it can be concluded that there is a significant difference between the experimental and control group participants. This conclusion is clearly shown in the following bar figure.

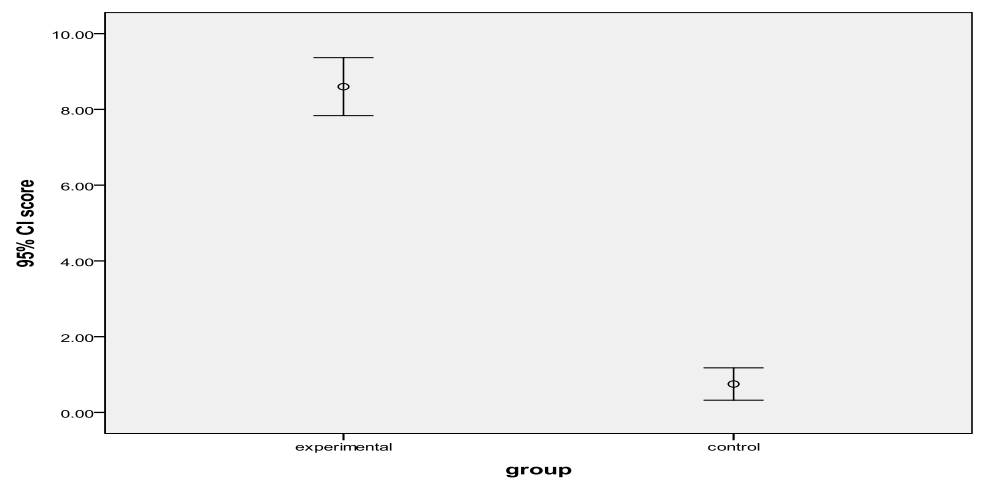

Figure 2 T-test Bar Diagram 


\section{Qualitative findings}

This section reports on the findings obtained through the analysis of the nine questions on the questionnaire administered to the learners to gauge their general perceptions toward the application of cell phones. Thus, in what follows the questions are going to be discussed based on the sequence in which they appeared on the questionnaire.

Q1. Do you own a mobile phone?

Since all the students had cell phone and their answers were all positive, there is no table for this question.

Q2. What do you normally use your mobile phone for?

TABLE 7

THE FREQUENCY TABLE FOR THE USE OF MOBILE PHONES

\begin{tabular}{|c|c|c|c|c|c|}
\hline & & Frequency & Percent & $\begin{array}{l}\text { Valid } \\
\text { Percent }\end{array}$ & Cumulative Percent \\
\hline Valid & $\begin{array}{l}\text { phone talk and } \\
\text { SMS }\end{array}$ & 20 & 100.0 & 100.0 & 100.0 \\
\hline
\end{tabular}

There were three options (phone call, SMS, and phone call and SMS) in this question; the results depicted in the above table, reveal that 100 percent of test takers had marked the third option, phone call and SMS. In other words, all of the participants were found to use cell phones for both talking and sending SMS. This piece of finding has also been shown in the bar diagram below.

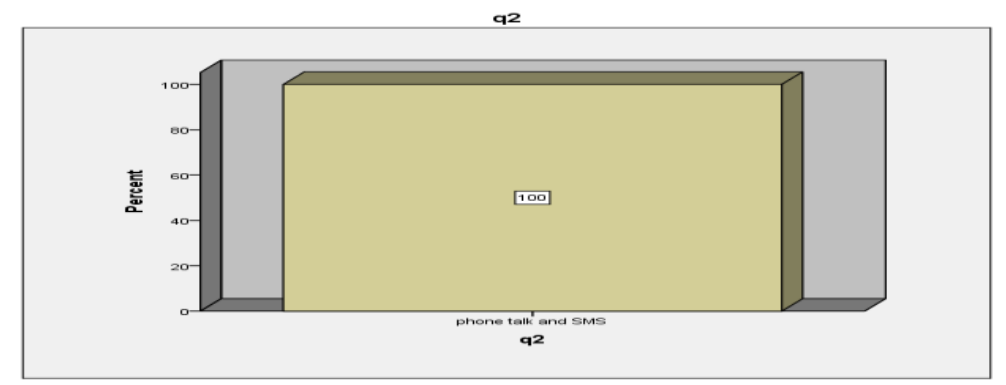

Figure 3 Bar Diagram Relevant to the Use of Mobile Phones

Q3. What is your average monthly SMS utilization?

TABLE 8

THE FREQUENCY TABLE FOR AVERAGE MONTHLY SMS UTILIZATION

\begin{tabular}{|ll|l|l|l|l|}
\hline & & Frequency & Percent & Valid Percent & Cumulative Percent \\
\hline Valid & $0-99$ & 17 & 85.0 & 85.0 & 85.0 \\
& $100-199$ & 2 & 10.0 & 10.0 & 95.0 \\
& $200-299$ & 1 & 5.0 & 5.0 & 100.0 \\
Total & 20 & 100.0 & 100.0 & \\
\hline
\end{tabular}

The upshots gained as to the third question, based on Table 8 , demonstrate that $85 \%$ of the testees claimed that they send 0-99 messages, 10\% of them sent 100-199 and the remaining 5\% sent 200-299 SMSs per month. The relevant bar diagram is shown below.

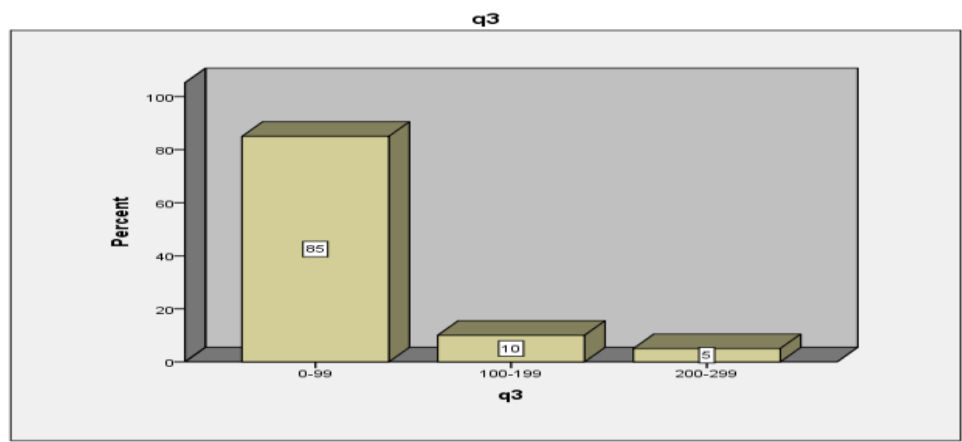

Figure 4 Bar Diagram Relevant to Average Monthly SMS Utilization

Q4. Are you currently pursuing any studies as either a full- or part-time student?

The respondents were required to only answer Yes or No to this question, and since they were all students of English at the ILI which can be regarded as a kind of part-time study, their replies were all Yes. So $100 \%$ of the testers were following part time English studies. This upshot is illustrated in Table 9 as well as in Figure 5. 
TABLE 9

THE FREQUENCY TABLE FOR PURSUING STUdies AS A FULL- OR PART-TIME STUdENT

\begin{tabular}{|l|l|l|l|l|}
\hline & Frequency & Percent & Valid Percent & Cumulative Percent \\
\hline Valid yes & 20 & 100.0 & 100.0 & 100.0 \\
\hline
\end{tabular}

q4

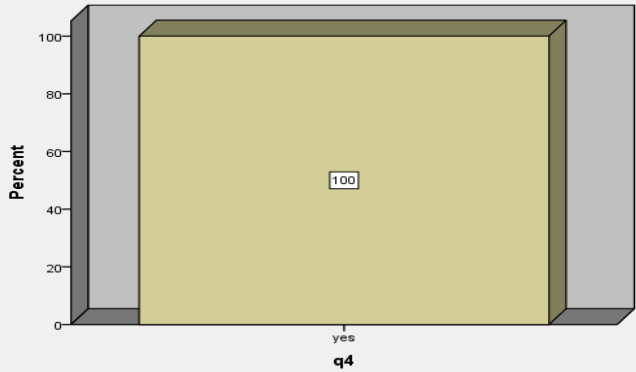

Figure 5 Bar Diagram Relevant to Pursuing Studies as a Full- or Part-Time Student

Q5. How frequently would you do your English studies through SMS?

To answer this question, five options (every day, once a week or more, once a month or more, during exam period and not applicable) were included. The students' replies were actually based on how frequently they would receive information about the words to be learned on their cell phone, and exchange the necessary information in order to understand the applications of the words and their meanings. All the participants had marked once a week or more due to their involvement in the current project in which they were sent SMSs on a regular weekly basis. The detailed data in this regard are shown in Table 10 and Figure 6.

TABLE 10

THE FREQUENCY TABLE FOR THE FREQUENCY OF ENGLISH STUDIES THROUGH SMS

\begin{tabular}{|l|l|l|l|l|}
\hline & Frequency & Percent & Valid Percent & Cumulative Percent \\
\hline Valid once a week or more & 20 & 100.0 & 100.0 & 100.0 \\
\hline
\end{tabular}

95

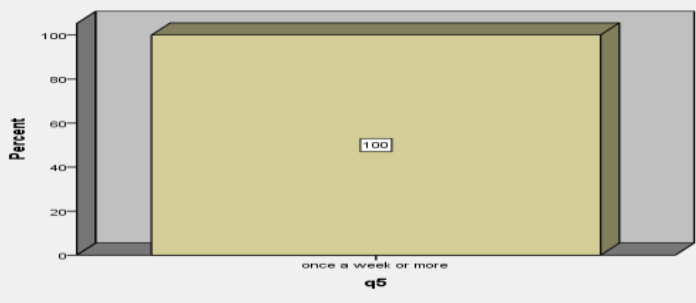

Figure 6 Bar Diagram Relevant to the Frequency of English Studies through SMS

Q6. Do you think your existing SMS utilization method is good?

TABLE 11

THE FREQUENCY TABLE FOR SMS UTILIZATION METHOD

\begin{tabular}{|ll|l|l|l|l|}
\hline & Frequency & Percent & Valid Percent & Cumulative Percent \\
\hline Valid & yes & 16 & 80.0 & 80.0 & 80.0 \\
& no & 2 & 10.0 & 10.0 & 90.0 \\
& maybe & 2 & 10.0 & 10.0 & 100.0 \\
Total & 20 & 100.0 & 100.0 & \\
\hline
\end{tabular}

96

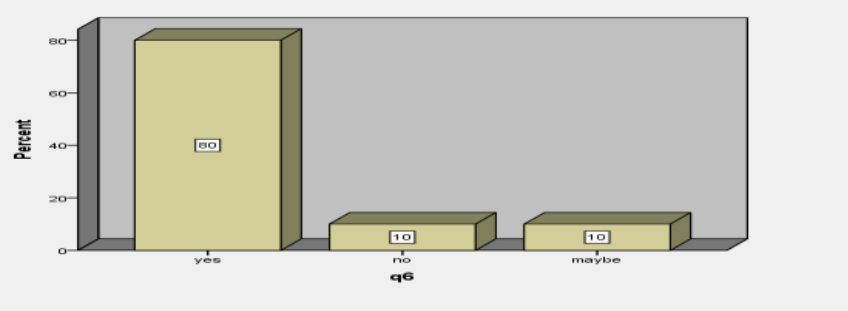

Figure 7 Bar Diagram Relevant to SMS Utilization Method 
In responding question 6 which had three possible options (Yes, No and Maybe), 80\% had marked Yes because they really liked this new way of learning based on the gathered data, whereas $10 \%$ had marked No since, based on the interview results, they thought it took time for them to cope with such a new trend of learning. Yet, the remaining $10 \%$ marked Maybe owing to their uncertainty as to the best alternative suiting them (For getting a better grasp of the outcomes for this research question refer to Table 11 and Figure 7).

Q7. Do you think SMS is useful in education?

TABLE 12

THE FREQUENCY TABLE FOR SMS UTILITY IN VOCABULARY LEARNING

\begin{tabular}{|c|c|c|c|c|c|}
\hline & & Frequency & Percent & Valid Percent & Cumulative Percent \\
\hline \multirow[t]{3}{*}{ Valid } & yes & 17 & 85.0 & 85.0 & 85.0 \\
\hline & maybe & 3 & 15.0 & 15.0 & 100.0 \\
\hline & Total & 20 & 100.0 & 100.0 & \\
\hline
\end{tabular}

$85 \%$ of the students (17 out of 20) had marked Yes since they believed they could learn vocabularies much better through the MALL-operated approach utilized in the current study. Furthermore, while none of the respondents marked No, 15 percent ( 3 out of the whole population of 20 in the experimental group) marked Maybe due to the fact that working with cell phone needed the skill of quick typing and reading in their opinions.

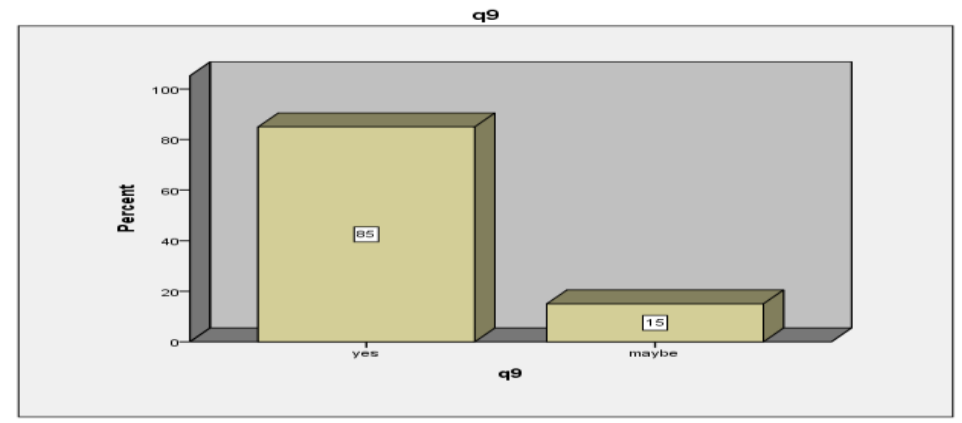

Figure 8 Bar Diagram Relevant to SMS Utility in Vocabulary Learning

Q8. If SMS application is implemented in education sector, which of the following services would you be interested in participating in? (Five options were included: Strongly Interested, Interested, Neutral, Useless, and Definitely Not)

TABLE 13

THE FREQUENCY TABLE FOR SMS ALERT

\begin{tabular}{|ll|l|l|l|l|}
\hline & & & & Cumulative \\
\hline \multirow{2}{*}{ Valid } & Frequency & Percent & Valid Percent & $\begin{array}{l}\text { Percent } \\
\end{array}$ \\
& interested & 16 & 80.0 & 80.0 & 80.0 \\
& being neutral & 2 & 10.0 & 10.0 & 90.0 \\
& Total & 20 & 10.0 & 10.0 & 100.0 \\
\hline
\end{tabular}

\section{8a. SMS Alert:}

In this question the majority of the testees, i.e. $80 \%$ was found to be strongly interested in SMS alert since they were highly motivated to use SMS as a vital device in their current life, $10 \%$ were just interested, and the remaining $10 \%$ were neutral. Indeed, none of the participants had marked Useless and Definitely Not interested as their choices (see Table 13 and Figure 9 below.

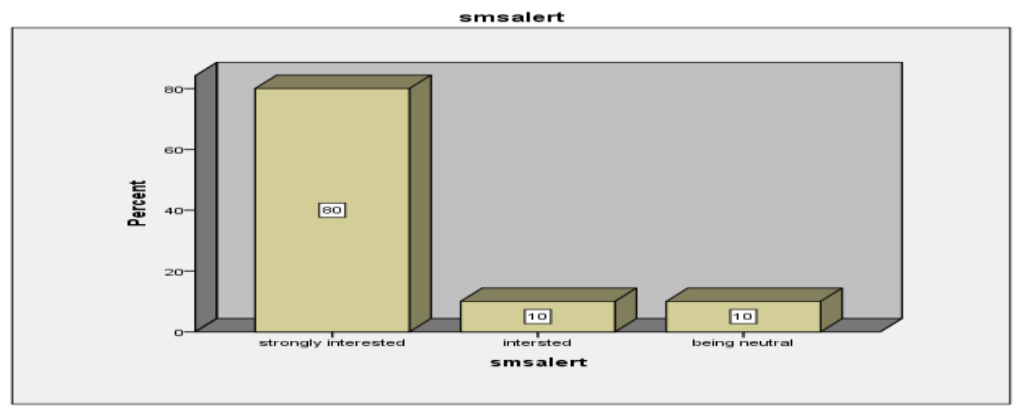

Figure 9 Bar Diagram Relevant to SMS Alert 
TABLE 14

THE FREQUENCY TABLE FOR SMS CHAT

\begin{tabular}{|ll|l|l|l|l|}
\hline & Frequency & Percent & Valid Percent & $\begin{array}{l}\text { Cumulative } \\
\text { Percent }\end{array}$ \\
\hline Valid & strongly interested & 18 & 90.0 & 90.0 & 90.0 \\
& interested & 1 & 5.0 & 5.0 & 95.0 \\
being definitely not & 1 & 5.0 & 5.0 & 100.0 \\
interested & & & & \\
Total & 20 & 100.0 & 100.0 & \\
\hline
\end{tabular}

With regard to question $8 \mathrm{~b}$ almost all the testees, i.e. $90 \%$ were strongly interested in SMS chat (as they revealed in interview session, they were highly motivated to use SMS for chatting in current life). Moreover, $5 \%$ of the participants were simply interested in it, and the rest had opted for definitely not interested in SMS chat, because as they later remarked in their interviews they believed that they could do more important things by mobiles than chatting with others. None of the subjects, yet, had marked option 3 (neutral) or option 4 (useless) (see Table 14 and Figure 10).

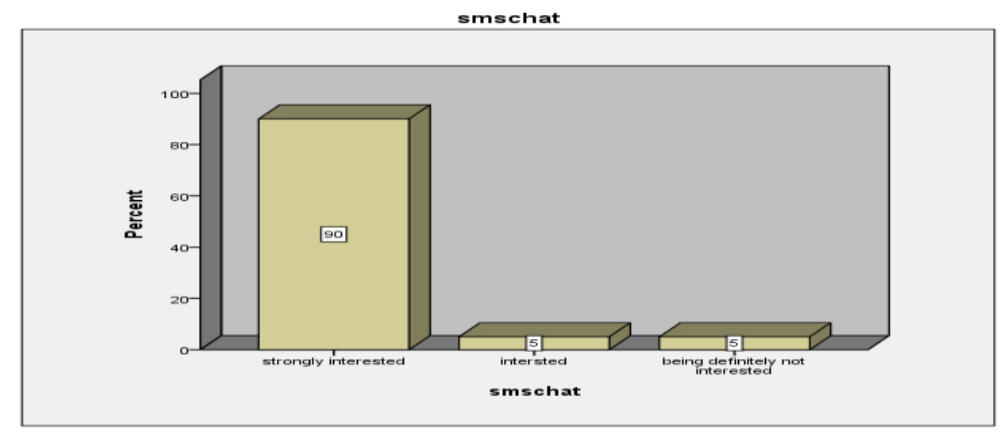

Figure 10 Bar Diagram Relevant to SMS Chat

\section{8c. SMS Game:}

TABLE 15

THE FREQUENCY TABLE FOR SMS INFORMATION EXCHANGE GAME

\begin{tabular}{|ll|l|l|l|l|}
\hline & Frequency & Percent & Valid Percent & $\begin{array}{l}\text { Cumulative } \\
\text { Percent }\end{array}$ \\
\hline Valid & strongly interested & 8 & 40.0 & 40.0 & 40.0 \\
& interested & 8 & 40.0 & 40.0 & 80.0 \\
being neutral & 1 & 5.0 & 5.0 & 85.0 \\
no interesting & 1 & 5.0 & 5.0 & 90.0 \\
being definitely not & 2 & 10.0 & 10.0 & 100.0 \\
interested & & 100.0 & 100.0 & \\
Total & 20 & & \\
\hline
\end{tabular}

$40 \%$ of the learners were strongly interested in getting new information out of the newly played games, $40 \%$ were merely interested but not highly motivated to do so, 5\% were neutral toward it, 5\% were not interested in SMS game, and the rest (10 percent) were definitely not interested in doing that (see Table 15 and Figure 11).

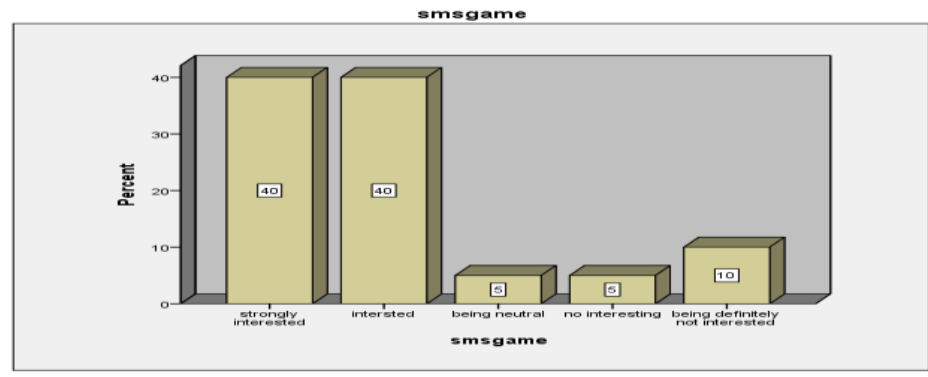

Figure 11 Bar Diagram Relevant to SMS Information Exchange Game

8d. SMS Information:

As Table 16 and Figure 12 reveal, $65 \%$ of the learners were strongly interested in getting new information and sending it through SMS exchanging, $20 \%$ were interested but not highly motivated to do so, $5 \%$ were neutral toward it., and the remaining $10 \%$ were definitely not interested in doing that. 
TABLE 16

THE FREQUENCY TABLE FOR INFORMATION EXCHANGE THROUGH SMS

\begin{tabular}{|ll|l|l|l|l|l|}
\hline \multicolumn{2}{|l|}{ Valid } & Frequency & Percent & Valid Percent & Cumulative Percent \\
& strongly interested & 13 & 65.0 & 65.0 & 65.0 \\
& interested & 4 & 20.0 & 20.0 & 85.0 \\
& being neutral & 1 & 5.0 & 5.0 & 90.0 \\
& being definitely not interested & 2 & 10.0 & 10.0 & 100.0 \\
& Total & 20 & 100.0 & 100.0 & \\
\hline
\end{tabular}

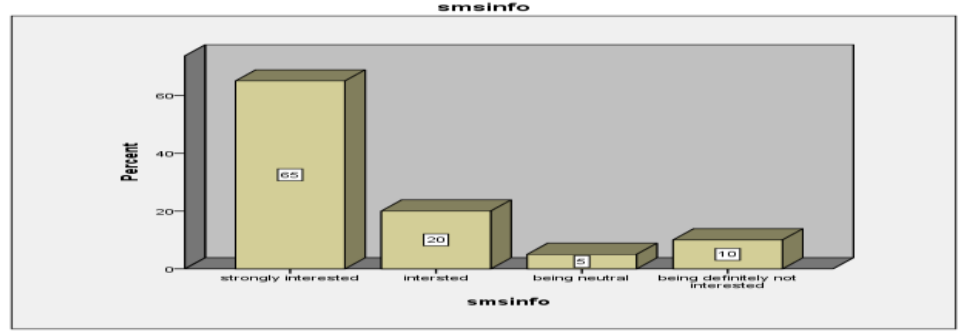

Figure 12 Bar Diagram Relevant to Information Exchange through SMS

\section{8e. SMS Tutoring:}

TABLE 17

THE FREQUENCY TABLE FOR SMS TUTORSHIP

\begin{tabular}{|ll|l|l|l|l|}
\hline & Frequency & Percent & Valid Percent & $\begin{array}{l}\text { Cumulative } \\
\text { Percent }\end{array}$ \\
\hline Valid & strongly interested & 12 & 60.0 & 60.0 & 60.0 \\
& interested & 5 & 25.0 & 25.0 & 85.0 \\
& being neutral & 2 & 10.0 & 10.0 & 95.0 \\
being definitely not & 1 & 5.0 & 5.0 & 100.0 \\
interested & & & & \\
Total & 20 & 100.0 & 100.0 & \\
\hline
\end{tabular}

In response to this item, which was partially relevant to the principal hypothesis of the current research, $60 \%$ of the students were found to be strongly interested, 25\% interested, 10\% neutral, and 5\% were definitely not interested (for more details refer to Table 17 and Figure 13).

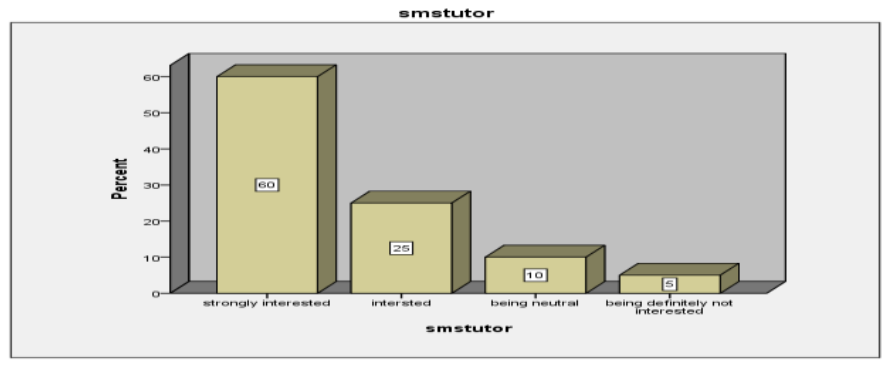

Figure 13 Bar Diagram Relevant to SMS Tutorship

Q9. On a scale of 1 (most important) to 5 (least important), please rate the following factors in order of importance that you would consider in using the SMS application:

9a. Convenience:

TABLE 18

THE FREQUENCY TABLE FOR THE CONVENIENCE OF SMS APPLICATION

\begin{tabular}{|ll|l|l|l|l|}
\hline & Frequency & Percent & Valid Percent & Cumulative Percent \\
\hline \multirow{2}{*}{ Valid } & most important & 14 & 70.0 & 70.0 & 70.0 \\
& very important & 6 & 30.0 & 30.0 & 100.0 \\
& Total & 20 & 100.0 & 100.0 & \\
\hline
\end{tabular}

Actually, question 9a was after determining the students' opinions about MALL and SMS application. Based on the gained results, $70 \%$ of learners thought it was the most important device to apply for learning and convenient to use, $30 \%$ thought it could be very important. Yet, the other three options (important, less important, least important), were not selected by any of the individuals (see Table 18 and Figure 14) 


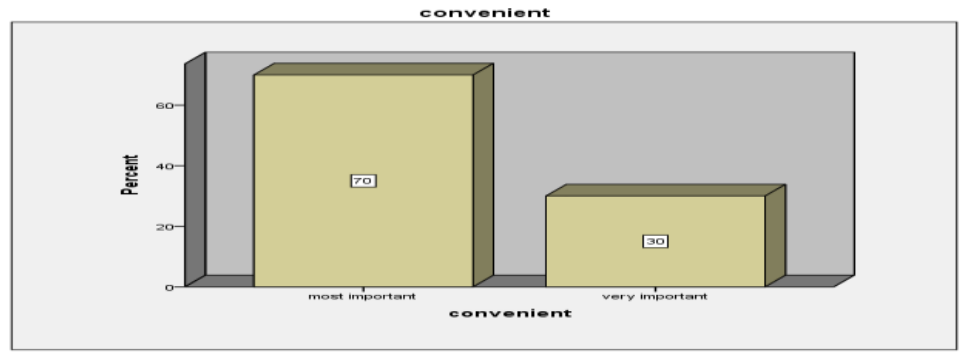

Figure 14 Bar Diagram Relevant to the Convenience of SMS Application

9b. Flexibility:

TABLE 19

THE FREQUENCY TABLE FOR FLEXIBILITY OF MOBILE AND SMS CAPACITY

\begin{tabular}{|c|c|c|c|c|c|}
\hline & & Frequency & Percent & Valid Percent & Cumulative Percent \\
\hline \multirow[t]{5}{*}{ Valid } & most important & 17 & 85.0 & 85.0 & 85.0 \\
\hline & very important & 1 & 5.0 & 5.0 & 90.0 \\
\hline & important & 1 & 5.0 & 5.0 & 95.0 \\
\hline & least important & 1 & 5.0 & 5.0 & 100.0 \\
\hline & Total & 20 & 100.0 & 100.0 & \\
\hline
\end{tabular}

As to question $9 \mathrm{~b}, 85 \%$ thought it was the most important, 5\% thought it could be very important, 5\% marked important, and $5 \%$ believed that it was less flexible (see Table 19 and Figure 15).

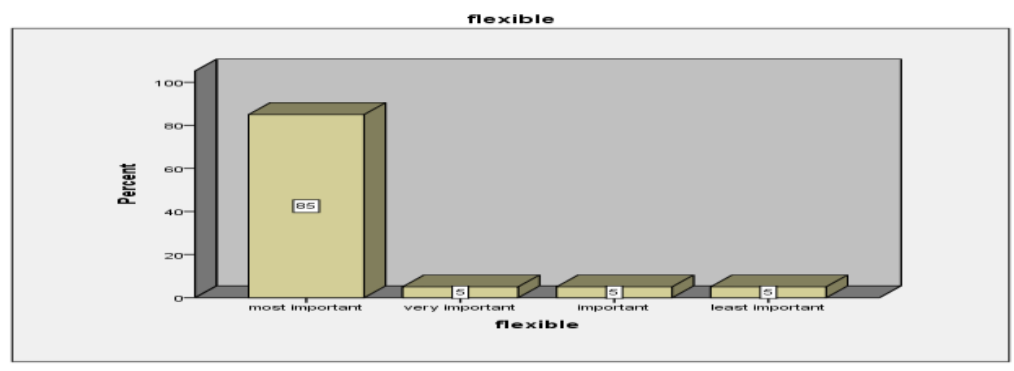

Figure 15 Bar Diagram Relevant to Flexibility of Mobile and SMS Capacity

\section{9c: Saving time}

This question was asked in order to find how much time the learners typically spent on SMS application and exchanging. $80 \%$ of the respondents thought it was the most important device to save time to learn, $10 \%$ thought it could be very important, and the other $10 \%$ stated that saving time for SMS application was important. Since they considered it as an important factor they hadn't marked options 4 and 5 (see Table 20 and Figure 16).

TABLE 20

THE FREQUENCY TABLE FOR THE USE OF SMS AS A MEANS OF SAVING TIME

\begin{tabular}{|ll|l|l|l|l|}
\hline & Frequency & Percent & Valid Percent & Cumulative Percent \\
\hline Valid & most important & 16 & 80.0 & 80.0 & 80.0 \\
& very important & 2 & 10.0 & 10.0 & 90.0 \\
important & 2 & 10.0 & 10.0 & 100.0 \\
Total & 20 & 100.0 & 100.0 & \\
\hline
\end{tabular}

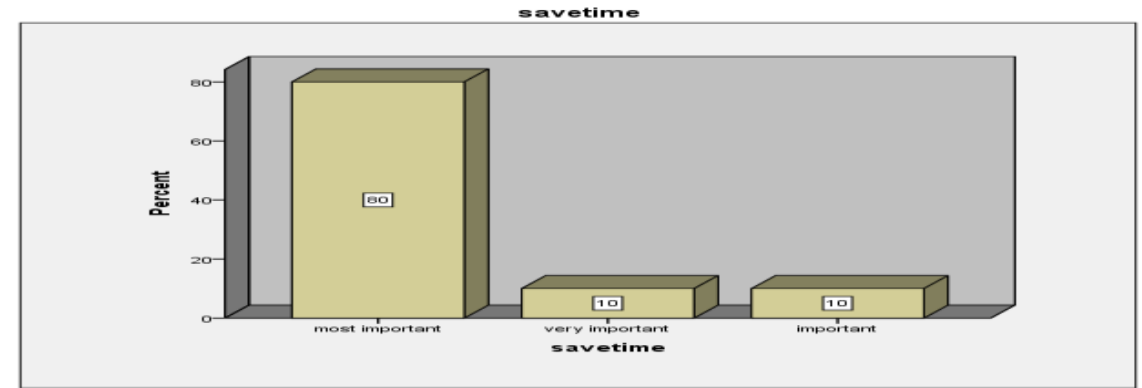

Figure 16 Bar Diagram Relevant to the Use of SMS as a Means of Saving Time 
TABLE 21

THE FREQUENCY TABLE FOR EFFECTIVENESS OF SMS APPLICATION

\begin{tabular}{|c|c|c|c|c|c|}
\hline & & Frequency & Percent & Valid Percent & $\begin{array}{l}\text { Cumulative } \\
\text { Percent }\end{array}$ \\
\hline Valid & $\begin{array}{l}\text { most important } \\
\text { very important } \\
\text { important } \\
\text { Total }\end{array}$ & $\begin{array}{l}10 \\
7 \\
3 \\
20\end{array}$ & $\begin{array}{l}50.0 \\
35.0 \\
15.0 \\
100.0\end{array}$ & $\begin{array}{l}50.0 \\
35.0 \\
15.0 \\
100.0\end{array}$ & $\begin{array}{l}50.0 \\
85.0 \\
100.0\end{array}$ \\
\hline
\end{tabular}

Question 9d was asked in order to find how effective the SMS application was. Based on the findings, $50 \%$ of participants thought it was the most important device for learning, 35\% thought it could be very important, and $15 \%$ stated that effectiveness of SMS application was important. Since they considered it as an important factor they hadn't marked option 4 and 5 (see Table 21 and Figure 17).

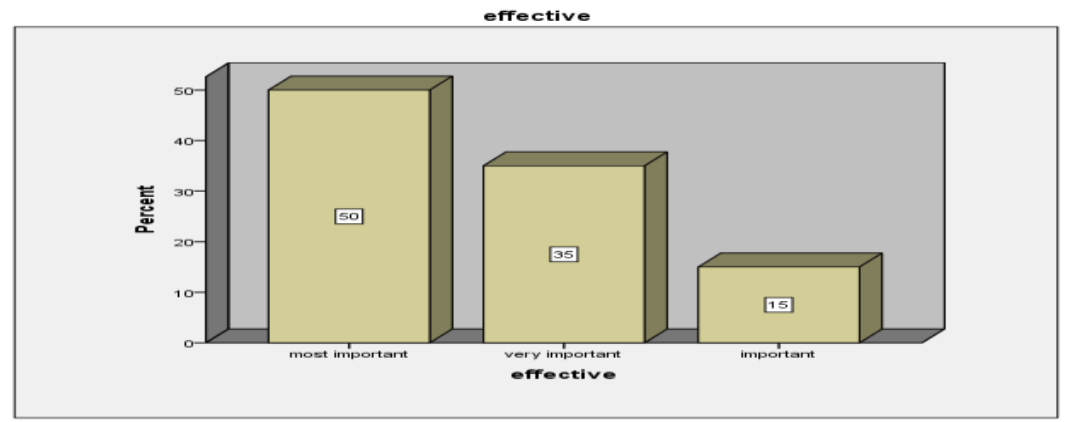

Figure 17 Bar Diagram Relevant to Effectiveness of SMS Application

\section{9e: Being Fun}

TABLE 22

THE FREQUENCY TABLE FOR SMS APPLICATION AS A FUN PURSUIT

\begin{tabular}{|c|l|l|l|l|}
\hline & Frequency & Percent & Valid Percent & Cumulative Percent \\
\hline Validmost important & 13 & 65.0 & 65.0 & 65.0 \\
very important & 4 & 20.0 & 20.0 & 85.0 \\
important & 2 & 10.0 & 10.0 & 95.0 \\
less important & 1 & 5.0 & 5.0 & 100.0 \\
Total & 20 & 100.0 & 100.0 & \\
\hline
\end{tabular}

In reply to question 9e, $65 \%$ marked the most important, $20 \%$ thought it could be very important, $10 \%$ opted for important, and merely $5 \%$ believed that it was less important to be busy with SMS application (see Table 22 and Figure $18)$.

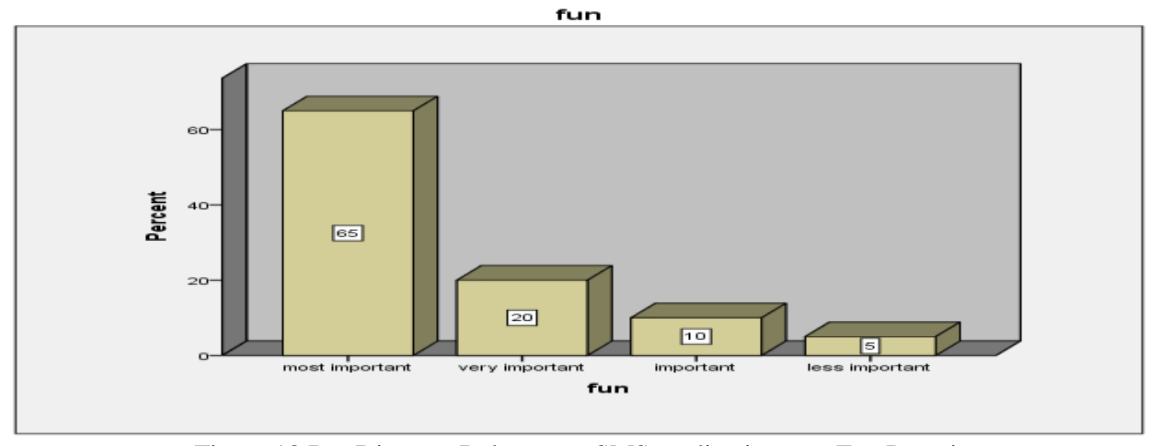

Figure 18 Bar Diagram Relevant to SMS application as a Fun Pursuit

\section{Interview}

Students in the current study were interviewed using some pre-designed questions, and each learner was given 5 minutes to answer them orally. Two sample interview items are presented below:

1. What are the factors, if any, Iranian EFL learners perceive to be impeding MALL practice?

2. What are your suggestions on actions to be taken to make MALL practice more effective?

Altogether, as the interview results revealed, the learners were all positive toward the effectiveness of MALL in the context of learning AND believed they couldn't do away with cell phones nowadays. However, some of them complained about their parents' lack of concern with regard to how and for what purposes they used mobiles. The other 
problem pointed out by interviewees was that they weren't permitted to have mobiles at schools. Finally, they recommended the use of cell phones for a variety of other purposes in language classes, including talking to one another in English and doing different exercises such as fill-in-the-blank, cloze tests, etc. using their mobiles.

\section{DISCUSSION}

The findings of the current study are in partial going with the results gained in Levy and Kennedy's (2005) research. To sum up what was gained in the present study, it should be reiterated that the analyses of data relevant to the first research question, pointed to the effectiveness of treatment in enhancing learners' vocabulary learning. In effect, the gained results indicated that the use of vocabulary learning program through the use of mobile phone (SMS) improved the students' vocabulary learning and their attitudes towards the use of mobile phones (SMS) for English vocabulary learning. It was also represented that using vocabulary learning programs on mobile phones would prove to be much more effective to improve students' vocabulary learning than using traditional paper-based resources. Finally, the findings showed that participants found learning English vocabulary on mobile phones effective and entertaining.

Qualitative data were found to strongly buttress this positive piece of finding, as well; indeed, participants referred to several positive aspects of the researchers' devised treatment during the interviews. All of the participants interviewed provided positive feedback about the mobile learning (SMS) application used in this study. The students stated that they enjoyed the instructional materials sent to their mobile phones during the experiment. All of the students stated that it would be better if their English language education were supported with instructional materials anchored to the use of mobile phones (SMS) like the one they used during the experiment.

\section{CONCLUSION}

Based on the findings of the present study, it can be concluded that even in circumstances where full access to digital resources is not possible, students can be encouraged to make active use of technology through their handheld, nifty devices, i.e. their cellular phones. Students are motivated enough to purchase and use these devices primarily because of their convenience. Thus, the teachers' pivotal role in the classroom might be that of tailoring active use of such useful devices to class context and familiarizing the learners with the proper utilization of such resources for educational purposes.

Text-messaging tools, as one of the focal utilities of cell phones, provide an effective means of teaching students important 21 st-century skills. Further, tools like cell phones can help foster the development of communities of practice and learning words among students and teachers. Cell phones and other text messaging tools can also help motivate and encourage students to do more writing and to express themselves through their writing. Additionally, SMS tool is thought to support and reinforce other instances of learning such as social learning, in that it can trigger more interactions between and among students. After all, in today's rapidly changing world students will need to understand and master the use of 21 st-century technological tools to effectively communicate and collaborate together.

\section{REFERENCES}

[1] Akenaga, Y. (2005). Mobile-Campus Solution. Paper presented at Mobile Learning for Expanding Educational Opportunities Workshop, 16-20.

[2] Alderson J.C. \& Banerjee, J. (2001). Impact and washback research in language testing. In Elder C, Brown A, Grove E, Hill K, Iwashita N, Lumley T, McNamara T \& O'Loughlin K (Eds.). Experimenting with uncertainty: Essays in honour of Alan Davies (pp 150-161). Cambridge: Cambridge University Press.

[3] Bordbar, F. (2010). English teachers' attitudes toward computer-assisted language learning. International Journal of Language Studies (IJLS), 4 (3), 27-54.

[4] Chaudron, G. (2000). Progress in language classroom research. The modern Language Journal, 85, 57-67.

[5] Cohen, L., Manion, L., \& Morrison, K. (2007). Research methods in education. New York: Routledge.

[6] Eswaran, J. (2008). Investigating the ESL teachers' and students' attitude towards the use of computer in English language classroom. Unpublished Thesis. Faculty of Education. University Technology Malaysia.

[7] Godwin-Jones, R. (2011). Emerging technologies: Mobile apps for language learning. Language Learning \& Technology, 15 (2), 2-11.

[8] Hafner, C. A., \& Miller, L. (2011). Fostering learner autonomy in English for science: A collaborative digital video project in a technological learning environment. Language Learning \& Technology, 15 (3), 68-86.

[9] Horwitz, E. K. (2000) Teachers and students, students and teachers: an ever-evolving relationship. The modern Language Journal, 84, 523-535.

[10] Kukulska-Hulme, A., \& Shield, L. (2008). An overview of mobile assisted language learning: From content delivery to supported collaboration and interaction. ReCALL, 20 (3), 271-289.

[11] Levy, M., \& Kennedy, C. (2005) Learning Italian via mobile SMS. In Kukulska-Hulme, A. \& Traxler, J. (Eds.), Mobile Learning: A Handbook for Educators and Trainers (pp. 76-83). London: Taylor \& Francis.

[12] McGinley, K. (2006). The 'test of interactive English' - from conception to implementation. ELT Journal, 60 (4), $374-382$.

[13] Milanovic, M. (2007). Studies in language testing 11. Cambridge: Cambridge University Press.

[14] Peters, K. (2007). M-Learning: Positioning educators for a mobile, connected future. International Review of Research in Open and Distance Learning 8 (2), Retrieved from http://www.irrodl.org/index.php/irrodl/article/view/346/882 
[15] Sauro, S. (2009). Computer-mediated corrective feedback and the development of L2 grammar. Language Learning \& Technology, 13 (1), 96-120.

[16] Stockwell, G. (2010). Using mobile phones for vocabulary activities: Examining the effect of the platform. Language Learning \& Technology, 14 (2), 95-110.

[17] Tanner, M. W., \& Landon, M. M. (2009). The effects of computer-assisted pronunciation readings on ESL learners' use of pausing, stress, intonation, and overall comprehensibility. Language Learning \& Technology, 13 (3), 51-65.

[18] Vinagre, M., \& Muñoz, B. (2011). Computer-mediated corrective feedback and language accuracy in telecollaborative exchanges. Language Learning \& Technology, 15 (1), 72-103.

[19] Yu, G. (2007). Students' voices in the evaluation of their written summaries: Empowerment and democracy for test takers? Language Testing, 24, 539-572.

Parviz Alavinia got his PhD in TEFL/TESOL from Allameh Tabataba'i University in Tehran, Iran, 2010, his MA (in the same major) from The University for Teacher Training in Tehran, Iran, 2004, and his BA degree from Urmia University, Urmia, Iran, 2001. $\mathrm{He}$ is currently involved as a full-time assistant professor and staff member at Urmia University. His main areas of interests include psycholinguistics, philosophy of language, critical discourse analysis, task-based instruction, and particularly emotional intelligence.

Kamel Qoitassi holds an MA in TEFL from Urmia Islamic Azad University (Science and Research Branch). He got his BA in TEFL from Islamic Azad University (Maragheh branch), Iran, 2001. He is mainly interested in studies on CALL, MALL and TBI. 